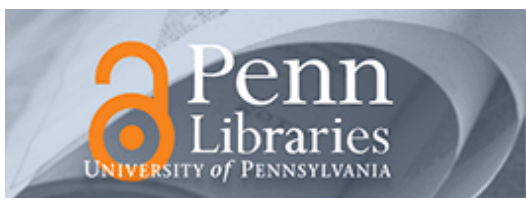

University of Pennsylvania ScholarlyCommons

Department of Anthropology Papers

Department of Anthropology

1967

\title{
Notes on the Baluchī Spoken in Persian Baluchistan
}

Brian Spooner

University of Pennsylvania, spooner@sas.upenn.edu

Follow this and additional works at: http://repository.upenn.edu/anthro_papers

Part of the Anthropology Commons

\section{Recommended Citation}

Spooner, B. (1967). Notes on the Baluchī Spoken in Persian Baluchistan. Iran, 5 51-71. Retrieved from http://repository.upenn.edu/ anthro_papers/135

This paper is posted at ScholarlyCommons. http://repository.upenn.edu/anthro_papers/135

For more information, please contact libraryrepository@pobox.upenn.edu. 


\section{Notes on the Baluchī Spoken in Persian Baluchistan}

\section{Disciplines}

Anthropology | Social and Behavioral Sciences 


\title{
NOTES ON THE BALUGHİ SPOKEN IN PERSIAN BALUGHISTAN
}

\author{
By Brian Spooner
}

I

I. The material which follows has been gathered during some twelve months anthropological field work (spread over the last three years) in the Persian Province of Sistan and Baluchistan, excluding the šahristān of Zābol or Sīstān (hereafter referred to simply as the Province). The language of the Administration is of course Persian, but outside the major settlements few people are bilingual, and probably as much Urdu as Persian is known - which is very little. Baluchī is the lingua franca of all natives of the Province (except a few Persian and Sikh merchants in the main towns) both in the settlements and the nomad encampments. Another language, Jadgāli - said to be derived from Sindhi, is spoken by a few thousand people - the Jadgāl tribes - in Dashtiārī in the extreme southeast of the Province, but these also use Baluchī as a lingua franca, and all the men are bilingual in these two languages. Brāhui is not spoken in the Province (as defined above, though I am told it is spoken by nomadic communities within the area of the šahristān of Zābol) but its influence is evident in the vocabulary of all the Baluchi dialects. This influence has been noted on the other side of the border in Pakistan in particular by Morgenstierne (esp. I932a and b), and in a recent published comment on the relationship between the two languages it has been suggested that future research " will bring to the attention of linguistic scholars something unprecedented (I believe) in linguistic reporting, an instance of symbiosis over a large area of two genetically unrelated languages, between which there has taken place not only structural borrowing (demonstrated previously for these two languages) but even a structural borrowing which shows parallel divergences on the two sides " (Emeneau, I964: 75-76). Morgenstierne ( $1932 \mathrm{a}: 9 \mathrm{ff}$.) noted the scale of interchange of vocabulary between the two languages, and considered it likely that some communities (in Pakistani Baluchistan) had changed from one language to the other more than once. Furthermore, he did not consider that either of the two languages possessed any cultural predominance as compared with the other.

2. This is not the place to attempt to account for the modern line of division between Persian and Pakistani Baluchistan. It is a complicated story and we do not possess sufficient historical evidence to account for it satisfactorily. However, two things are relatively certain:

i. the main factors were political-in the form of alliances and enmities between Baluch leaders. (I am preparing a monograph on the subject of Baluch political activities and concepts.)

ii. the process may be said to have started with the "legitimization" of the Khānate of Kalāt by Nādir Shāh in I739, which was later confirmed by the British in India. The British may be said to have fossilized the western extent of the influence of the Khān of Kalāt and treated it as their far northwestern border, although the border was not actually defined until much later (187 I, cf. Aitchison, C. U. (Comp.) A Collection of Treaties, Engagements and Sanads . . Calcutta, I933, Vol. XIII : I4) when renewed Persian interest in the area necessitated a settlement. The Khannate of Kalāt was the only paramount native Baluch political power which can be said ever to have attained any degree of legitimacy, and certainly the only one to have had that legitimacy recognized formally by a foreign power.

3. The relevance of this to a discussion of language is that the institution of the Khānate of Kalāt gave rise in time to the beginning of a consciousness of nationhood and unity even among those Baluch who did not own allegiance to it, which in turn was the basis for the first attempts to write the Baluchi language and therefore a gradual tendency towards standardization of the language. But all this was confined to British (now Pakistani) Baluchistan. There is now an official monthly magazine published in Quetta in Baluchī, and other occasional publications appear from time to time in Quetta and Karachi. The standard language which is slowly being formed approximates to what is generally thought of as the Makrānī dialect and contains a large number of new loan words from Urdu. Nothing 
comparable has happened in the Persian Province, and although there is a growing awareness there now of what is happening over the border very few Persian Baluch, though literate in Persian, when confronted with the Pakistani publications are able to read their own language-even though it is in the same alphabet (with a few minor modifications).

4. The Baluchī spoken in Persian Baluchistan then is an unwritten, unstandardized and unrationalized language. There is no conception among its speakers of what is correct and what is incorrect speech. Rather they think, obviously, in terms of what is intelligible, or unintelligible, or funny because it is an unusual mode of expression, or marks the speaker out as coming from a particular area or class. There is tremendous pride in poetry, and particularly in the traditional epic poetry (cf. Dames, 1907). This may be considered something of a standardizing influence, but as is often the case-even though poetry is very much a living art-it tends to be more conservative than everyday speech and even to cultivate archaisms. The meaning of some of these archaisms has been forgotten, with the result that a transcription and study of the old epic poetry still recited in the Province today would require expert " textual " criticism. Therefore, while it is definitely a linguistically unifying factor poetry by no means controls the development and diversification of ordinary speech.

5. A corollary of this is that although the Baluch take great pride in their language and in the art of expression in prose and poetry, they tend not to be conscious of lexical or even structural borrowings - which in the present context means mainly Persianization. For these reasons it is often not feasible in a description of the language - which must remain basically a description of recorded speech-either to generalize from or account for all elements. We must be content rather in some cases simply to say "I heard this said ", and indicate similar modes of expression and contexts in the same and (sociologically) related languages.

6. The bibliography given at the end of this paper is designed to include all the significant or useful publications relevant to the study and analysis of the Baluchì spoken in the Persian Province. It will be noticed that none of the items listed refers specifically to this form of Baluchi (with the minor exceptions of items I 5 and I6). In fact, there is (so far as I have been able to trace) no significant published information based on first-hand information about it. I have taken this in itself as a sufficient justification for publishing the material which follows.

7. This article therefore is designed to be complementary to already existing publications on what are generally known as the Western or Southern dialects of Baluchī-in particular, the Makrānī, Panjgurī, Marwì dialects. Items I4, I9, 26, 40 of the bibliography are useful as general introductory descriptive grammars. Short comments are given to indicate the relevance and usefulness of each individual item in the bibliography. In general it must be remembered that each of these grammars attempts to reduce the language to general grammatical principles or rules. Although it is of course the job of the philologist to attempt this type of reduction, as we have already pointed out it may be misleading so far as the present usage of particular forms of the language are concerned. In such a language, speech may be divided into two categories:

(a) Sentences, phrases and idioms which have become stereotyped--the natural way to express certain ideas, and

(b) new modes of expressing new ideas.

The former may contain modes of expression which compared to the latter are archaisms.

The word list in item 26 is particularly useful. After these works I found item 2 the most useful publication in my own efforts to acquire facility in the use of the language.

8. The main section of this article is in the form of an annotated word list, but before proceeding to this a few remarks concerning general grammar and dialect differences may be useful. My aim is to present those items and aspects of the linguistic idiom of the Province which differ from already published information on the language in general. Purely philological comments are reduced to a minimum, since I write as a social anthropologist who learnt to use the language as a tool for researchI have no formal training in philology or linguistics. Nevertheless I hope the article will also show that the social anthropologist may make some contribution to the study of languages - if only because of the opportunities (and the need) he has for acquiring familiarity with them, and because basically his job 
is comparable to that of an interpreter anyway. For this reason and since it is natural that dialect variation should first affect the colloquial core of a language, I should like to think that the data given in this article, without constituting a general purpose phrase book, also represents a cross-section or "characterization" of everyday linguistic expression through the medium of Baluchi in the Province. Throughout the article, references are made to other works only where the material seems to be complementary, corroborative or contradictory to them. Basically, then, I list and comment briefly on grammatical and vocabulary usage which I have found which is not published elsewhere, or which differs from or may serve to illuminate obscurities or insufficiencies in published sources.

II

I. The vocabularies used to express time, distance, and kinship and marriage relations and the analysis of the basic conceptions which these vocabularies represent are reserved for future publication. The repertoire of personal names in use and the local toponymy will also be discussed at greater length elsewhere, but a few general remarks may be relevant here. The Baluch are predominantly Hanafi muslims, and naturally a large proportion of their personal nomenclature is derived from those Arabic names which figure in the history of the first century of Islam. However, they also include a few traditional Baluch and a number of " heroic" Persian names, and in general the nomenclature in use shows great variety. They are particularly fond of compound names. Thus, from Muhammad which they pronounce Mahmad they form Alī Muhammad, Dīn M., Dorr M., Dust M., Feiz M., Golām M., Gol M., Hatā (A. 'Ața) M., Jān M., Heir M., Lāl (A. La'l) M., Nìk M., Nizar M., Nur M., Pakīr (A. Faqīr) M., Šeih M., Šìr M., Tāj M., Walì M., M. Akbar, M. Alī, M. Amīn, M. Hasan, M. Karīm, M. Morād, M. Omar. Several of these compounds are (to my knowledge) either non-existent or rare in the rest of Persia, but are found among other tribal communities in Afghanistan and West Pakistan. Cf. also Imām-bahš, Karīm-bahš, Lāl-bahš, Nabī-bahš, Pīr-bahš, Rahīm-bahš, Tāj-bahš; Allah-dād, Kāder-dād, Hālek-dād, Maulā-dād, Šah-dād; Dād-allāh, Dād-šāh, Dād-rahmān; Jom‘a, Šamba, Došamba, Cār-šamba, Panj-šamba, but never yak-šamba, or sei-šamba, though it is said that these also are used in Bashākerd.

2. Place names may be divided into three types:

(a) Old names of presumably pre-Islamic origin, most of which feature in one or other of the early geographies (e.g. Hudüd al-'Älam, trans. etc. V. Minorsky, E. J. Gibb Memorial New Series XI, I937: I 23, 373). These were there before the Baluch entered the Province and have remained unchanged to the present day. They are almost exclusively names of agricultural centres. (One of these-Khẉāsh-is in fact called in Baluchī "Wāsh(t)".) Cf. also Kant, Naskant, Kaserkant (P. Qasr Qand) and Misc.: 289.

(b) Names of Baluchī origin - or at least Baluchī in form. These are predominantly names of rivers, streams, rocks, mountains (but not the two highest peaks in the Province-Kuh-i Taftān or Ceheltan and Kuh-i Zenda or Bazmān -which must have provided unforgettable landmarks and perhaps watering places, from very early times on important routes which passed to the north and south (?) of them) and small areas. That is, the names of Baluchī origin or form suggest the toponymy of a pastoral, nomadic people.

(c) New Persian names, mostly ending in " -ābād", which belong almost entirely to small, new agricultural settlements started in the present century, or at least since the renewed Persian interest in the Province in the middle of the last century.

3. A few general points regarding vocabulary are interesting:

The usage of loan words of Arabic and Persian origin, though they are generally thought to have come to Baluchī through Persian, often does not coincide with standard Persian usage. For instance, P. taqsim kardan is in Baluchī báhar kanag, and for P. 'avaz kardan Baluchī uses badal kanag. In several cases Persian Baluchī shares similar usage of A./P. loan words or phrases with Afghan Persian, Urdu, and/or Persian dialects spoken in Eastern Persia, which are not found in standard or other forms of Persian. Some of these similarities are indicated in the word list. 
4. It is practically certain (though difficult to prove to any great extent-a problem which will be discussed in a future publication) that the majority of speakers of Persian Baluchi are not of Baluch ethnic origin (whatever that may be) and did not speak Baluchī when they entered the Province; also that immigrants into the Province have represented each of the languages which now neighbour Baluchī, even though now all call themselves Baluch, are excepted as Baluch, and (except for the small Jadgālì-speaking minority) all speak Baluchī as their mother tongue.

5. Finally, names of plants and varieties of pedigree date-palms are excluded from the list, mainly because of difficulties of identification.

I. Baluchĩ is a very conservative Iranian language. Phonetically and grammatically (both syntax and accidence) it is also very simple. Its historical development, its diversity and adaptability are seen in its vocabulary and wealth of idiomatic expression. Allusion has already been made to the amount of lexical borrowing, and it is mainly for this reason that the main section of this article is in the form of a word list. It is the vocabulary and idiom which presents the major barrier to acquiring a useful degree of proficiency in the language - together with the diversity of usage from one dialect to another. Nevertheless, certain details of grammar seem to me (as a non-philologist) still to require explanation. The following points which I have observed in the usage of the language in the Persian Province are offered as a contribution.

2. I Past stems. It is generally thought that the past stems of all transitive verbs are used as though they were passive only. Morgenstierne, who of all writers has probably the broadest first-hand knowledge of Baluchì, writes ( 1947 ):

"The so-called 'passive" construction of transitive verbs in past tenses was, no doubt, the original one, and still prevails in some Western dialects. Thus, $\bar{e}$ mard $\bar{a} \bar{a}$ mard jat, this man struck that man; $\bar{e}$ mardā hamā mard kushtagant, this man killed these [sic!] very men. In some dialects, however, the object is put in the accusative dative: marda apsära kushta, the man killed the horse; or the construction has been completely changed into the ordinary Persian one: $\bar{e} z \bar{a} g \bar{a} z \bar{a} g \bar{a} j a t$, this boy struck that boy; jan u mart go wat kaul kurtant, the woman and the man made an agreement between them " (for more detail cf. also Misc. 260). In the Persian Province also the usage varies. Analysis is complicated by the fact that the pronominal suffix may be added to the verb to indicate the (logical) subject, and for the first person the pronominal suffix and the personal ending of the verb are identical. Thus, the first person singular of the preterite zórt-on, and the perfect zorté-on or zortág-on may be interpreted as either active or passive constructions. In the second person singular there is a complication: the second person singular pronominal suffix is identical with the third person singular ending of the verb for the pluperfect: e.g. zorté-at or zortág-at. This form tends to be reserved for the latter purpose, which means that it is difficult to say "you have taken" in the passive construction without emphasizing the personal pronoun, thus: tau zorta. This point must surely be taken into consideration when accounting for the active construction zortē or zortagēe. In the third person singular zórt-ī or zortág-ī may again be interpreted as passive-i.e. he took it or he has taken it - or may be compared with Persian use of the enclitic personal pronoun to indicate the (at least, logical) subject, e.g. góft-aš ke . . = he said that . . Note also that two pronominal suffixes may be added to the verb to indicate the (logical) subject and object respectively: e.g. zórteš̀ $=$ they took it. cf. G(onābādī) :vā-stundá-š-ì.

2.2 The use of the plural is mentioned again below in connection with the noun. In general speakers tend to avoid the plural in the first and second persons and the third person used for people, but tend towards it in the third person for inanimates and animals. With regard to the analysis of the construction similar ambiguities arise.

2.3 Pronominal suffixes apart, it makes sense to treat the active past construction as a Persianism. It is for the most part confined to Sarāvān and bilingual speakers in Persian administrative centres.

3.I The usage of the tenses of the verb is almost identical to that of Persian, except that there is no specific future tense or periphrasis and there is only one subjunctive tense-that formed from the present or imperfective stem. Other differences are peculiar to the Sarāvān dialect and will be discussed below (IV). 
3.2 The subjunctive may or may not be distinguished from the present/future, imperfective tense by the addition of the prefix "be-". The principle involved seems to be similar to modern Persian usage. For example:

$\bar{a} p$ beyār dast o dēma shudān = bring some water for me to wash my face and hands;

zahir-et-int ke jā-é berawēe? = lit. are you homesick to go somewhere?

These are the normal ways of saying two very common sentences. It would be equally "correct" but unusual to use $b e$ - in the first example. It would change the meaning to omit it in the second example. The imperative usually only takes $b e$ - in verbs beginning with a vowel, e.g. bey $\bar{a}$-come, beyar-bring, but $p \bar{a} d-\bar{a}$ - get up, $b a r$ - take away. When used with the imperative $b e$ - is not stressed.

3.3 The variety of forms used to express the various tenses of " to be " and " to become " may make clearer the usage of these three-tenses-in-one. Basically, in normal usage, these ideas are expressed by the defective verb beag, and a series of enclitic forms, thus:

(a) bān I am becoming, will become, will be, may be

bèn we etc.

$b \bar{e} \quad$ you etc.

bit you etc.

$b u(t), b i(t)$ he, she, it, etc., also, it is possible cf. P. mišavad bant they etc.

$b e-$ may be used in the subjunctive but is omitted when the distinction it affords is not explicitly required.

(b) bo = imperative: be, become.

(c) -on am

$-\bar{e} \quad$ are

-int is (Sarāvānī-o)

$-\bar{e} \quad$ are

-it are

With past participle of other verbs, this form is used to form the perfect tense.

Negative: ná-(h)on, etc.

(d) $h a(s t)$ it exists, there is, i.e. emphatic form of the above enclitic. The other persons are said to exist, but seem to be rarely used.

Negative: nēst.

(e) -aton was

$-a t \bar{e} \quad$ were

-atèn were

-at was

-atit were

With past participle of other verbs, used to form pluperfect.

-atant were

Negative: $n a ́ a-(h)$ aton, etc.

(f) hásta $(t)=$ it existed, there was-as hast.

Negative: néstat.

(g) but-on, etc. = I became, etc.

(h) buta $(g)=$ perfect participle: having become, having been.

(j) butág-on or buté-on, etc. = (i) I have become, etc.:

(ii) I was, etc., in the sense in which P. budé-am is used to express a fact in the distant past, as opposed to a step in a narrative. (Cf. Lazard, G. Grammaire du Persan Contemporain, Paris, I957: I44-45.)

(k) butág-aton, or buté-aton etc. = I had been or had become, etc., i.e. previous to remainder of context.

Where not shown the negative of each of these tenses is formed simply by prefixing " ná-", which takes the stress. The negative of the enclitic forms thus becomes non-enclitic.

I believe the distribution of the meanings of "be" and "become" through these forms (with the additional help in some cases of context) in fact precludes ambiguity, despite the apparent confusion which confronts the Persian speaker attempting to learn the language. 
4.I Little needs to be added to what is already written about the noun. The following inflections are used in the Province:

(i) $-\bar{e}$ indefinite article (enclitic).

(ii) -än plural.

to which are added:

(iii) -i genitive (unstressed).

(iv) -i $g$, - $-\bar{g}$ absolute genitive, usually only used with personal pronouns and proper nouns-manig $=$ mine, Bahrämīg = Bahrām's. This inflection seems only to be used in the oblique case (i.e. with $-\bar{a}$ added) or in front of the copula.

(v) $-\bar{a},-a$ oblique case. (Cf. Morgenstierne, I947, paragraph commencing "The grammar is simple ..." and Misc. 257.)

4.2 An interesting point of Baluchī idiom is that, whereas for instance Persian speakers always tend to use the singular of nouns and third person singular verbs and pronouns for plural inanimate objects, Baluchi tends firmly towards the plural. For instance, bring the tea (for more than one person) is always cah-ấn-a beyār. On the other hand Baluchì has no use for honorifics, and never uses the plural for a single person in either the second or the third person of the verb.

4.3 The enclitic particle $r \bar{a}$ seems not to be used except to form the acc. and dat. cases of the personal pronouns tárā, márāa šomár $\bar{a}$.

5. I The third person pronoun is $\bar{a} \imath$ (cf. below, VI (i) I.2), "he" and "she "— " it" tends to

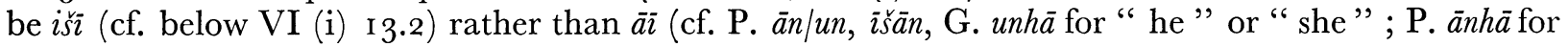
" they" ; more normally in for " it").

5.2 The second person is tau, gen. $t e i$, and $t i$ which are also used after prepositions - but $t i$ is often heard for the nominative also, particularly in Sarāvān. Absolute genitive-te-ìg.

6. I Adverbs are formed with the suffix $-a k+$ the obl. case ending $-\bar{a}$, thus: huraka $\bar{a}$ together, $z u t a k \bar{a}=$ quickly, tahnak $\bar{a}=$ alone.

6.2 The suffix -ok may be attached to any noun or adjective to form a diminutive e.g. hordokếné $=$ a small one.

6.3. All adjectives take the suffix $-\bar{e} n$ when used attributively, even when the noun is understood, e.g. iši tuhếne int $=$ this is a large one. Numerals also take the suffix before a definite noun (which may be understood), e.g. pakat mā sei-èn (napar) rawèn = just the three of us are going; $\bar{a}$ dau-èn paläs = those two tents.

\section{IV}

I. I That usage and vocabulary varies from area to area and village to village is certain, but pinning down the variations with any certainty is difficult (without spending much longer periods in individual villages and communities than I have been able to do) because of the perpetual and complicated patterns of movement which affect not only the whole population of the Province but also involve linguistic influence from dialects on the other side of the border in Pakistan. In this situation there is a continual give and take between dialects. Nevertheless two major differences stand out:

I.2 In any area there is always some dialect variation between the pastoral (nomadic) and the agricultural (settled) sections of the population. It is natural that the range of vocabulary should vary from one to the other. However, in some areas there are more general dialect variations between the two which must be due to patterns of migration and historical origin. For instance, in the Sarāvān area the settled agriculturalists use māt, pet, brät, while the nomadic pastoralists use the forms mās, pes, brās (cf. Misc. 258).

I.3 There is a definite dividing line to be drawn between the dialects spoken in the Sarāvān area and those spoken in the rest of the Province. That several of the stronger tribes in the Sarāvān area most likely have Persian or Afghan origins may be the main cause of these differences. The dialects of the Sarhadd similarly distinguish themselves from the rest of the Province but I have not spent sufficient time in that region to be able to give a useful account of them. 
2.0 The following are the main features which distinguish the Sarāvānì dialects from the speech of the Makrān:

2. I In general these dialects may be said to be closer to Persian.

2.2 The infinitive is formed from the perfective (or past) stem $+\bar{e} n-$ e.g. kortenn $=$ to do, makerather than the imperfective (present) stem + ag-e.g. kanag.

2.3 The Persian idäfat (P. ezäfa) construction tends to be used instead of the normal Baluchi genitive construction. All the dialects of Baluchi throughout the Province are mutually comprehensible, but this particular feature of Sarāvāni can lead to confusion. For instance, the following was an actual exchange between a Sarāvānī and a Makrānī with whom I was recently discussing the usage of the word nešar:

$\begin{array}{ll}\text { Sarāvānī: } & \text { jan-i cok nešār int } \\ \text { Makrānì: } & \text { jáni cok ...!? } \\ \text { Sarāvānī: } & \text { jan-i-ke cóka ge }(p t)\end{array}$

A son's wife is called nešăr

A wife's son ....!?

A wife which a son takes (lit. took-notice tendency always to drop final consonants.)

2.4 In perfective stems of verbs -tk- (which becomes - $x t$ - in the Eastern dialect) becomes - $h t$ - in Sarāvānī (cf. Misc. 255), e.g.

Sarāvānī
yāyag, yahta
ducag, dohta
géjag, gehta
rēcag, rehta
sucag, sohta

Makrānī
āyag, ätka
dutka
gètka
rētka
sutka

Eastern
axta
doxta
$\quad ?$
rexta
soxta

cf. verb list in Grierson, I92 I : 350-52. Other verbs which might be expected to change in the same way-e.g. bujag - are not used in Sarāvānī. It is interesting also to compare the Marwī forms of the past participles of these and similar verbs (cf. Marw, passim): they lack the - $h$ - of the Sarāvāni forms, but have compensated by lengthening the preceding vowel.

2.5 The continuous tenses formed from the infinitive of the imperfective stem + the obl. $\bar{a}+$ the enclitic form of the verb " to be "—warag $\bar{a}-o n$, warag $\bar{a}$-aton-are not used in Sarāvānì. Instead a peri-

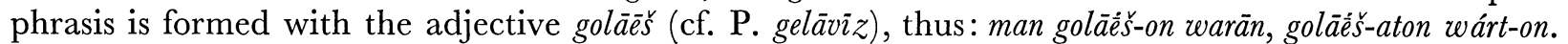
Thus the simple past tense is used in Sarāvān as an aorist and an imperfect.

2.6 Sarāvānì drops the final $g$ of the past participle before a suffix, thus: yahté-on = I have come; $m \bar{a}$ dāsté-at $=$ we had stopped.

2.7 Sarāvānī makes far more use of compound verbs, for instance: pac kanag for bujag; prämuš (P. farämuš) kanag for šamušag.

2.8 Some Sarāvānĩ dialects do not use the absolute genitive, but instead employ cei similarly to the Persian māl, thus: iš̃ cei mána int $=$ this is mine.

\section{V}

The representation of the language in writing is problematical because:

(a) the pronunciation varies from place to place,

(b) the precedents already set are not always consistent or satisfactory,

(c) it is desirable to spell in such a way as not to disguise philological connections.

If a standard orthography had been evolved in the Urdu script by the Baluchī publications in West Pakistan, the task would be easier, but this is not the case. The system used here has been worked out with these points in mind. It is felt that for the reader with a knowledge of Iranian languages the values of the letters used should be self-explanatory, except for the following points:

I. Initial $h$ is often dropped, or added where it does not belong, i.e. it is not phonemic.

2. Any final consonant (but not clusters) may apparently be doubled at will, except when followed by a word beginning with a consonant. 
3. Final consonants (inc. clusters) at a pause tend to be dropped, the preceding vowel being nasalized when the consonant is an $n$ (or the first consonant of the cluster is an $n$ ).

4. Any word ending in final short $a$ may take a final $g$ (e.g. past participles) and in most dialects (except Sarāvānī) normally does so before an inflexion or a word beginning with a vowel.

5. The following vowels are particularly difficult to distinguish between in many cases because of variation in pronunciation: $\bar{\imath}$ and $\bar{e} ; \bar{e}$ and $e i$. (My $e i$ is normally represented elsewhere as $a i$ or $a y$.) It is similarly often difficult to distinguish between long and short $a$, and in the obl. case ending this difference does not appear to be significant.

6. In general Sarāvānī keeps long $u$ while most other dialects have changed it to $\bar{\imath}$. There does not seem to be a phonemic difference between this long $u$ (where it is retained) and a sound which is something between a long $o$ and long $u$. For this reason I have represented all long back rounded vowels as $u$, and short ones as $o$, since there seems to be no phonemic differentiation within each.

7. It is generally thought that $f$ and $x$ not only do not exist in Western Baluchi but cannot be pronounced by Western Baluch. However, in the Persian Province both $f$ and $x$ are occasionally heard. The actual situation would seem to be that there is no phonemic distinction in the province between $p$ and $f$, and $h$ and $x$, but that the tendency is always to pronounce $p$ and $h$ respectively. It is interesting to note that there is (at least) one instance of $x$ becoming $k$-in kandag = to laugh (cf. Misc. 254).

8. The combinations ' $a$ and $a^{\text {' }}$ in A. or P./A. loan words (except where ' is intervocalic) become $\bar{a}$, e.g. mälum, ärusì. Intervocalic ' is simply dropped, e.g. Ra-is.

9. The traditional distinction of "long" and "short" vowels in both Persian and Baluchi does not seem to be adequate for the analysis of the ordinary spoken language (cf. Sokolova, I953: $9 \mathrm{ff}$. and I $5 \mathrm{ff}$.). In Persian speech in general the distinction is one of quality, not of quantity. We have already noted that in Baluchì inflexions in the Province there does not seem to be any distinction between long and short $a$. In some positions long $a$ is reduced to $a h$, e.g. yaht for $\bar{a} t k$ (cf. above, IV, 2.4), also -ahn for ann in Pahnuc for Fannuc, and -oh- for $u$ in Banfohl for Bampur-though the form Banfohl is not now known in the Province and I have only met it in Persian texts, and below (VI (vii), 49) pohn and pun.

I0. Baluchī uses a large number of loan words which are predominantly of Arabic, Persian, Brāhui, Urdu, or Sindhi origins. It is interesting that although the Arabic, Persian and Brāhui loanwords contain phonemes which are strange to Baluchi it has not adopted them but has modified them to fit its existing phonemic system, whereas in the Urdu and Sindhi loanwords it has retained the retroflex dentals (cf. Geiger, ı898-igor : 234, Notes: 38 and Misc. 256). In Baluchi words in the following word list $d, t$, and $r$ represent the retroflex consonants. In non-Baluchi words the diacritical dots are used according to the normal canons of Arabic/Persian transliteration.

I I. The first person singular personal ending of the verb is pronounced $-\bar{a} n$ when stressed (in the present/future/subjunctive), but on when not stressed (in all other tenses). (It will be remembered that the traditional transcription varies between $a$ and $u$.) The $n$ is usually only pronounced before a suffix; otherwise the vowel is nasalized.

12. The stress is always on the final syllable unless otherwise shown.

\section{VI}

In the word list, which is given here, words which are obviously (at least in part) Persian and not Baluchī in form whether of Iranian or other origin, and are likely to be old loanwords from Persian are marked $\dagger$. Of verbs the infinitive only is given, except where the third person singular present and/or the past participle are formed irregularly from it, in which case the irregular parts are also given at the first occurrence.

The arrangement is in twelve sections:

(i) Adverbs, prepositions, particles, demonstratives.

(ii) Verbs.

(iii) Adjectives.

(iv) Abstract nouns. 
(v) Domestic.

(vi) Domestic animal terms.

(vii) Pastoral and agricultural.

(viii) Social relationships and statuses.

(ix) Institutions.

(x) Parts of the body.

(xi) Food.

(xii) Time.

Within the sections the order is alphabetical except that synonyms and certain other closely related groups of words are kept together. It is felt that in a list of this length (only 455 items) the inconvenience of the lack of strict alphabetical order is outweighed by the simplification of cross referencing.

I.I $\bar{a}=$ that - demonstrative adjective.

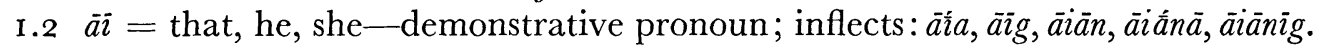

2.I $\bar{a}$-dèm $=$ on that side, over there.

$2.2 \tilde{a}-g o(r)=$ in that direction, there $(\bar{a}+g w a r)$.

$2.3 \bar{a}-k e s$-ter $=$ a little further that way.

3. $a c a=$ well, then; e.g. aca bwar oda $=$ well, eat it then.

4. I cinkalinka)

4.2 cinco/inco $\}=$ how much, how many/some. Note: dau inka = twice as much.

$4 \cdot 3$ cont $=$ how much, how many.

5. $\quad \cos (\bar{\imath})=$ thus, like this $($ co/cun $+(i) r(i))$. Cf. Marw: 29 .

6. I $\quad$ dar $=$ out, e.g. dar àyag $=$ to come out.

6.2 dâr $\bar{a}=$ outside, as also, dánn $\bar{a}=$ lit. in the plain

$6.3 j \bar{a} n-d a r=$ naked $(j \bar{a} n=$ body). Also, jān darā $k u=$ he undressed. Cf. Gershevitch, I962: 82-84.

7. dard in pa dárda nábi $(t)=$ he won't be offended.

8. I $d a u l=$ way, manner, e.g. a daúla $=$ in that way, cf. peim (below I8); also Marw: 34 .

8.2 daul-dār = "posh "-looking, impressive.

9.I $\bar{e}=$ this, demonstrative adjective; forms $\bar{e}$-dèm, $\bar{e}-$-go, $\bar{e}-k e s-t e r$ as $\bar{a}$ above 2.I-3.

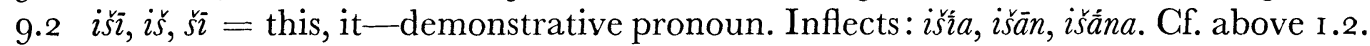

Io. go/gun $=$ with. Note: $\bar{a}$ dagār go mána $(i n t)=$ that plot of land is mine (sc. to till, though I may not actually own it); $\bar{a}$ dagār manig int $=$ that plot of land belongs to me. Also, mána zar $h a(s t)=\mathrm{I}$ have (own) money; mána zar gun (int) $=\mathrm{I}$ have money on me. Also, e.g. Gol Mahmad gun at gun $=$ (sc. we went somewhere and) Gol Mohammad came with us.

II. godd $a=$ afterwards, then. Cf. Marw: 35 .

12. hanga $(t)=$ still (P. hanuz). Cf. Marw: I 4 , angät.

13. hannu $=$ now.

I4. $j a m\left(\right.$ P./A. jam $\left.^{c}\right)$ in pa jam $=$ (all) together; synonym of hurakä.

I5. $j i=$ particle showing respectful attention, with which speech addressed to superiors tends to be started. Standing on its own it signifies a positive answer. The negative is expressed by ji na, or ji inna.

I6. $k a s ̌ s, k e s$, cf. above 2.3 and 9.I. Also yak-káša $=$ continuously, without break.

I 7 . oda/ode $=$ well, then.

18. peim $=$ manner, way. Note: har peimèn $=$ whatever sort of; -peima $=$ (postpos.) like; peim kanag synonym of ad kanag (ii), 2 I. I and P. dorost kardan.

I9. $\operatorname{rand}(a)=\operatorname{after}($ wards) - postpos. and adv. Cf. Marw: 67 .

20. I tanigah.

20.2 taniwahd $(\bar{i})$ (P./A. waqt) $\}=$ till now.

21. $\quad t u ́ k a=$ in the middle, adv. and postpos.

22. $w a=$ enclitic particle inserted after word requiring emphasis, used as ke in P., e.g.ä̃ wa náyēt = he certainly will not come. 
(ii)

I.I. ärag/yārag, (y) ārta/aorta = bring. Cf. P. ävardan/āvordan.

I.2 $p a j \bar{a}(h) \overline{a r a g}=$ recognize, remember (sc. call to mind). Cf. P. be-jā āvardan.

2. I àyag/yāyag, ket/yèt, ätka/yahta = come. The second form is Sarāvānī only.

2.2 pād āyag = to get up (from sleep or from lying position). Cf. Marw: 62.

3. I barag, bart, borta $=$ bring.

3.2 dam barag = be tired-temporary tiredness, out of breath (e.g. after climbing hill, as distinct from the adjective $\check{z} a n d)$. Note inflexion: man dám-a-barän=I shall get tired, it will tire me; man dam náborta $=\mathrm{I}$ am not tired; dámet borta? = are you tired?

4. I cand(ēn)ag (cf. Marw: 27).

$4.2 \operatorname{sor}(\bar{e} n) a g$

$4 \cdot 3 \operatorname{lar} z(\bar{e} n) a g$

5. $\quad$ cärag, cārta $=$ look (at).

6. I cinag, cint, cita $=$ (as P. cidan) pick-senses include chicken picking up grain with its beak, and setting down counters in a game or plates and cutlery on a table, i.e. picking up one thing, or setting down a number of things in place.

6.2 šalwāa $\operatorname{ba} \bar{a} \bar{a}(d)$ cin $=$ roll up trouser legs.

7.I dārag, dāsta = (a) hold, e.g. man celíma därān = I will hold the water-pipe (for you). (b) stop, e.g. $m \bar{a} \bar{d} \bar{a} t=$ we stopped (i.e. counts as transitive).

7.2 pēs därag $=$ show.

8. I deag, dant, dāta = give.

8.2 bon deag $=$ light (a cigarette).

8.3 dur deag $=$ throw (away).

8.4 rah deag $=$ send.

8.5 suj deag = lit. give guidance, advise, help.

9. dik beag/warag $=$ to meet with unexpectedly.

IO.I gallag $=$ flee.

I0.2 gallènag $=$ chase out/away.

I I.I gējag, gehta $/$ gettka $=$ to abort (of a sheep or goat)

I I.2 $c \bar{e} r$ gejjag = spread on the ground. Cf. Marw: 28 .

I I.3 dar gèjag $=$ find, seek.

II.4 $\bar{e}$ r gejjag = guide, or find path for (an animal), down a mountainside. Cf. Elfenbein, I96r: $95 \mathrm{n} .7$.

I2.I sar gerag, gepta $=$ to start making preparations for setting off on a journey.

I 2.2 kaläg gerag $=$ to make fun of $(k a l a \bar{g}=\mathrm{P}$. masxara $)$.

13. gê̌sag, gếsénag = finish (trans. and intrans.).

I4. hallet $=\mathrm{it}$ is finished, there is no more. Past: halleta.

I5. hur/hawär beag/kanag = join (trans. and intrans.), e.g. a group; hur lit. means " mixed together".

I6. heläs = finished, over (P./A. xaläs which is used similarly in Afghan Persian).

I 7. heirān: man heirân-on = I do not understand, I do not know what to do or say.

I8. jakkag = cough. Cf. Marw: 42 ..

I9. jallag $=$ stay over.

20. jokkag = kneel (of a camel).

$2 \mathrm{I} . \mathrm{I}$ ad kanag, kant, korta $/$ kota $=$ peim kanag (cf. above, (i), I8) $=$ P. dorost kardan $=$ make, put right, repair, prepare, etc.

2 г.2 bad kanag $=$ P. kul kardan $=$ take on one's back. Cf. Elfenbein, I96ı: 94 n. 6.

21.3 bahā kanag $=$ sell.

$2 \mathrm{I} .4$ báhar kanag $=$ divide, share out.

21.5 bèru kanag (Dashtiārī) = turn back, return.

21.6 cist kanag = remove, lift, take away. Cf. Elfenbein, I96r : 94 cikut-context seems to demand cist kut.

21.7 danı kanag (cf. above 3.2 dam barag) = rest a while to let temporary tiredness pass, get breath back. 
2 1.8 dar kanag $=$ take off (clothes, shoes, etc.). Also in cînka ruc dár-a-kant tā bérasē pa Karācía $=$ how long will it take you to get to Karachi.

2 I.9 dap kanag $=$ put in the mouth.

2 I. IO $\bar{e}$ r kanag = put down.

21. I I gap kanag = talk, hold conversation. Cf. P. gap kardan/zadan-more common in Afghan Persian.

Cf. also gapp o rap = joke, idle talk, P. šuxí.

2 I.I2 gwar kanag = put on (clothes).

2 I.I 3 habar/hawal kanag $=$ talk, speak.

2 I.I4 Jadgälì kanag = speak Jadgālì.

2 I.I 5 jost kanag $=$ ask.

21.16 meidān kanag, pa meidānā āyag/rawag (also in Sarāvān, as imperatives, betac and bejeh) = run.

2 I.I 7 mes kanag $/$ mizag $=$ urinate.

2 I.I 8 kap kanag $=$ crack or split open (e.g. pistachio nut). Cf. Marw: 48.

21.19 pacānk kanag = blow one's nose. In Sarāvān sar rēc is used instead of pacānk (pacānk =nasal mucus).

$2 \mathrm{I} .20$ päd kanag $=(a)$ wake, get up (trans.), $(b)$ put on (shoes).

2I.2 I pir kanag $=(a)$ put on, e.g. an extra blanket; $(b)$ to prepare a water pipe; $(c)$ to rise (of a river in flood).

$21.22 \mathrm{se}(\mathrm{h}) \mathrm{i} \mathrm{kanag} / \mathrm{beag}=$ inform, let know/know (in the sense of "to have information"). Cf. Marw: 69, si.

21.23 seil kanag = watch. Cf. seil kardan in Afghan Persian, and Marw: 72.

$2 \mathrm{I} .24$ tawär kanag = call, summon. Cf. Marw: 78 (tawär = noise).

$2 \mathrm{I} .25$ tec kanag $=$ spread (trans.) . Cf. also tec kašag = P. derāz kašidan.

2 1.26 wadī kanag (Sarāvān) = find. Cf. G. vadì kardan and wadī in Marw: 79.

21.27 warša kanag $=$ pound (in mortar).

$2 \mathrm{I} .28$ was kanag $=$ try, make effort.

22. I kapag, kapta $=$ fall.

22.2 ér kapag $=$ climb/come/jump down.

22.3 sar kapag $=$ climb/walk up.

22.4 pac kapag $=$ fall behind.

22.5 pēs kapag = get ahead, go on ahead.

23. pa kär beag = be necessary.

24. $\quad k a n d a g=$ laugh. Cf. Marw: 14 .

25. $\quad k e n z a g=$ move (a little), bekenz $=$ kammóki $\bar{a}$ kešter bo.

26. $\quad k o t t ̦ a g=(a)$ (Sarāvān) pound. Cf. Marw: 50; $(b)$ be finished, as helās beag, hallet.

27. $\quad$ laḍdag $=$ load, decamp. Cf. Marw: $5^{2}$.

28. $\operatorname{lag}(g) a g=(a)$ meet with, hit, touch; $(b)$ start (suddenly), as in laggit pa kandága $=$ he started to laugh. Cf. Marw: $5^{2}$ (?), and Geiger i 898-190 I : 234 .

29. $\quad$ lakošag $=$ slip, slide.

30. šterag (Dashtiārīi) = synonym of 29 .

3I. lek beag $=$ climb.

32. I lutag = want. Cf. Marw: 54 .

32.2 luțāênag $=$ summon.

32.3 Sarāvānī prefers the defective verb päestēn, which is impersonal in the present as well as taking the usual passive construction in the past, e.g. pásé mána pei $=\mathrm{I}$ want a sheep/goat; peit-et koja bérawēe ? = where do you want to go ? Also ce tau pei ? = what do you want?

33. $\quad$ mèn beag $=\operatorname{sink}$ (in mud).

34. uštag, uštäta = stand (i.e. the act of standing, to get up), imp. bušt. Cf. Marw: 18, ı9, and 20.

35. parākanag $=$ scatter, e.g. tóham parákanān $=\mathrm{I}$ am sowing seed.

36. pattag $=\operatorname{search}($ P. taftǐs $)$. Cf. patt o lut $=$ research.

37. potrag (lug) $=$ enter (in a manner that normally requires stooping). Cf. Marw: 65 . The phrase lug potrag is also used as an equivalent to bāhut below, (ix), 3 . 
38. sekkag = learn.

39. $\quad$ tahag $=$ to get on with, P. jur ämadan.

40. I tarr (ēn)ag, tar(ri)ta|tarrēnta $=$ P. gaštan, gardānīdan.

40.2 pac tarrag $=$ P. bar gaštan, return.

$4^{0.3}$ tarruk $=$ in training, P. varzida.

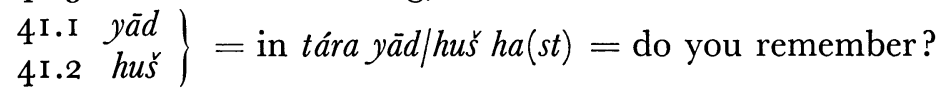

42.I yala kanag $=$ give up, P. tark kardan.

42.2 yala deag = let go, P. vel kardan.

43.I zurag, zorta = pick up, take.

43.2 pa baha zurag = buy.

43.3 máni habarána názure $=$ you do not listen/take any notice of what I say.

I. $\bar{a} g \bar{a} h=$ awake.

2. $\quad b \bar{a} z=$ (too) much, equivalent of P. ziād. Cf. Marw: 25 .

3. $\quad c e d d=$ marshy, waterlogged.

4. $\quad d a d d=$ well, strong, fit, skilful.

5. $\quad$ del-guš $=(a)$ thinking to oneself alone, lost in one's own thoughts. (b) Sympathetically attentive to what someone else is saying.

6. del-mānag $=$ expectant, in the sense of the P./A. motavaqqe - but perhaps not so strong.

7.I $\quad$ drost $=$ all. cf. Marw: 32 .

$7.2 \mathrm{koll}=$ all.

8. I ganuk $=$ mad, crazy-not so rude as

8.2 puk, for which cf. Marw: 62 .

9. $g \bar{a} r=$ lost, disappeared.

Io. gwand. Cf. Notes, 46: and Marw: 39 .

II. lok

I2. patak $=$ short.

13. jur $=$ well (especially in greetings). Cf. Marw: $4^{2}$.

I4. $k a l a n d=$ old, worn out.

I 5. $\quad m o c=$ plenty. Cf. Marw: 54, and Afshar, I 333:46 I .

I6. $n i z u r=$ weak.

I 7. I peidāg

I 7.2 zäher $\}=$ visible.

I8. I prāh $=$ wide.

I8.2 $\operatorname{prāh} \bar{i}=$ width.

I9. pottaruk in man pottarúk-on = I have indigestion.

20. $\quad$ sell $=$ bad, dirty.

21. $s o b a k=$ light (P. sabok).

22. $t a h \bar{a} r=$ dark.

23. taklīpi (cf. A./P. taklif) $=$ uncomfortable, troublesome. Also in Afghan Persian.

24. $\quad$ tayā $r=$ ready.

25. I mazan

$25 \cdot 3$ zand

26. I $z a b r$

26.2 šarr $\}=\operatorname{good}\left(w a s^{2}\right.$ also includes the sense of P. xwoš).

26.3 waš

27.I $j a h l=$ low; jahla $=$ low down; jahlä-ter $=$ further down.

$27.2 j u h l=$ deep, of well or gwalm, (below (vii) 24) etc. 
I. bongēj = foundation, P. bonyād.

2. do ̌zmān = insult; do ̌̌mān deag = swear at. Cf. P. došnām, and Marw: 33 .

3. dalwat $=$ riches - usually in the form of flocks, from A. daulat. Cf. P. mäl.

4. humän-desire-appears sometimes to include the meanings of hobb, hayāl (P./A. khiäl) and zahìr, below, I4. Cf. Marwe, I9, óman.

5. $\quad h o b b$ (P./A. hobb) = inclination, desire, P. meil.

6. jend + pronominal suffix $=$ self. Cf. Marw: 43 , jind $(\bar{\imath})$.

7. $\quad$ kalah $=$ message.

8. leib $=(a)$ game, P. bãzi (gwãzi is also used). (b) A scene, uproar, great fun, as P. ma'raka.

9. $\quad$ mesr $=$ a beautiful, luxurious place.

I0. $m o l k=$ one's own country, area-e.g. rawän (wáti) mólka $=\mathrm{I}$ am going home.

I I. $s a \bar{h}=$ soul, spirit, P./A. ruh.

12. $s \bar{a} r=$ consciousness; $b \bar{e}-s \bar{a} r=$ unconscious.

I3. sohrat = shame, P. xejälat.

14. $\quad z a h i r=$ longing, homesickness-e.g. zahis $r$-et-int $=$ are you homesick?

I5. $\quad z a h r(=$ P. qahr $)$ in zahr beag/gerag = be not on speaking terms, sulking/sulk.

$\left.\begin{array}{ll}\text { I.I } & \dagger \bar{a} b-r \bar{e} z \\ \text { I.2 } & \dagger a d a b-h \bar{a} n a \\ \text { I.3 } & \text { dēm-šu }\end{array}\right\}=$ lavatory, latrine.
(

The first two terms, which are Persian borrowingsthough I have not come across them in use in any form of Persian, appear to be restricted to certain tribes in the Sarāvān area; the third term is more general. The conception is in fact superfluous in most of the Province.

2. $\quad$ baca $(g)($ P. bacca $)=$ any male servant, slave (goläm) or otherwise, particularly as a term of address. Cf. similar usage in Afghan Persian.

3. $\quad$ bäkes $=\operatorname{match}(\mathrm{es})$.

4.I $b \bar{a} n=$ room built of mud or mud brick. (In this word the $n$ is not dropped or reduced to nasalization.)

4.2 dawär $=$ generic word for dwelling, also extended to mean wife.

4.3 gedān = tent, which may be either of black goat-hair or piš (23. I below). Cf. Marw: 35 .

4.4 ges = general word for dwelling used by the pastoralists in the Sarhadd.

4.5 käpar (I have also heard käfar). Cf. P. kapar, and Bashk. kavār in Gershevitch, I959: 2 I9 = shelter of branches and pis.

4.6 $k a t=$ a generic word for dwelling. Cf. Gershevitch, I959: 2 I9.

$4.7 k u t i \bar{c}=b \bar{a} n$ (above $4 . \mathrm{I}$ ) but $b \bar{a} n$ is usually bigger.

$4.8 \mathrm{koll}=$ type of square hut built of branches and mud with piš roof, mainly in south-east of Province.

Also name of tree.

4.9 paläs $=$ tent.

4. Io tup = as koll, but circular, larger and better built. Cf. Gershevitch, I959: 2 18-19.

4. I $\operatorname{lug}=$ the most general word for dwelling throughout Baluchistan.

5. $\quad b o l g a \bar{r} r=$ sediment which forms in water from inside of water-skin (mašk).

6. bäpāri $=$ merchant, tradesman.

7.I bond

7.2 gandal (used mainly in Lāshār)

7.3 lihëp (cf. Marw: 53, lep) (Sarāvān) $=$ the traveller's baggage and, esp., his blanket $(\mathrm{s})$.

7.4 napād (cf. Marw: 6o, nipad) (Makrān)

8. celīm = water-pipe, P. qalyān. Cf. Marw: 27, and Majalla-i Dāniškada-i Adabìyāt, Tehran, Vol. XIII, no. 3, p. 8r.

9. $\quad$ eśkar $=$ live embers or charcoal. 
I0.I $\operatorname{garib}($ A./P. yarīb) $=$ stranger, with associations of " poor ", " helpless".

I0.2 dar-ätk-ên $=$ stranger (without the above associations), visitor. Not used without the attributive suffix.

$\left.\begin{array}{ll}\text { I I.I } & \text { halk (P./A. xalq) (Sarḥadd) } \\ \text { I I.2 } & \text { métag }\end{array}\right\}=$ encampment.

I 2.I häkum (P./A. häkim)-used in the Province to mean ruler of a not always well-defined area, traditionally always centred on a fort in an agricultural settlement; implies the right to collect I/ Io (dah-yak) of the agricultural produce of the area in tax. Cf. Marw: I 2.

I 2.2 $k a m a \bar{s}=(a)$ one of the socially and politically important men in their community but only slang for important chiefs; $(b)$ the senior man in any particular situation.

I2.3. I wajja (P. $x w a \overline{a j a})=(a)$ of a third person, very respectful term of reference; $(b)$ respectful term of address; $(c)$ neologism for Mr. as P. $\bar{a} q \bar{a}$.

I 2.3.2 wāja-kär $=$ as $k a m \bar{a} \breve{s}$, but more respectful.

I3.I $h a s ̌=$ hand-mill, quern. Cf. Marw: I5, ashsh and parallels in Bashk, Kurd., and P.

I 3.2 jenter-synonym of haš, in use in Sarbāz area.

I4. $h e i k=$ egg.

I5. jäma = the long, full shirt, which together with šalwār make up Baluch male attire. Cf. Marw: 43 .

16. joll = woven rug, P. gelim - the only form of floor covering, besides piš mats, made in the Province. Cf. Marw: 43 .

I 7. $\quad k a l l a-d \bar{a} r=$ rupee. Cf. Marw: 46 .

I8. $\quad k a p a l=$ pottery made without wheel in Kalpurkān (Sarāvān).

I9.I makesk = fly/flies, mosquitoes. Cf. Marw: 55, magis.

I $9.2 \quad m a s ̌ n=$ fly (Sarāvān only).

I 9.3 šāsk = mosquito-mainly Sarāvān.

20. $\quad$ mauled $=$ female yoläm. Cf. Marw: 55 , molid.

21. $\quad p \bar{a} g=$ a type of hat with turban. pagg bandag $=$ to appoint as headman of village or tribe. Cf. Geiger I 893-I90 I : 234 .

22.I pändul $=$ intricately embroidered pocket on front of woman's shift.

22.2 jīg (in Lāshār-zih) = the embroidered bodice of the woman's shift.

23. I $p i \bar{s}=$ the leaves of two species of wild palmetto Chamaerops ( $d \bar{a} z$ and pork) which are put to innumerable uses, and of which the following items are woven.

23.2 duzmān $=p i \bar{s}$ string for sewing the seams of baskets woven of pis.

23.3 cīlik (mainly Sarāvān) = rope of pīs. Cf. säd below, 23. I I and Afshar, I 333:463.

23.4 jatk $=p i \check{s}$ dried and pounded ready for making sawäs (below 23.12).

23.5 $k a c=$ donkey panier of piš. Goat-hair panier is gwäl-cf. P. joväl.

23.6 kamag $=p i s ̌ s$ sieve for flour.

23.7 $k a p \bar{a} t=p i \check{s}$ bag for storing dates.

$23.8 \quad l a c=$ camel panier of piš.

$23.9 p \bar{a} t=p i s s$ container for storing wheat.

23. I0 $p a t=$ strip of plaited $p i s$ approx. 4 in. across.

23. I I $s \bar{a} d=$ rope of piš. Cf. cilik above. Also traditional measurement of length equal to 50 bagal (P.

$$
\text { bayal). }
$$

23.12 sawās $=$ piš sandals.

23.I3.I šahim = shallow piš tray used for scales.

23.13.2 amud = wooden bar from which are hung the two šahim, thus forming a pair of scales.

23.I4 sond $=$ pis basket.

23. I5. I tagerd $=$ mat woven of piš.

23.I5.2 pattar = tagerd spread out for diwän or assembly of important man.

23.1 6 tīcag $=$ piš container for grain.

23. I 7 tijīg $=$ rope on which sawäs are woven.

23.18. I $s a b d=$ tray of $p i s$ for feeding donkeys. 
23.18.2 tug = same as sabd.

24. $\quad$ poloh $=$ nose ring for women. Cf. Marw: 63 .

25. $\quad$ por $=$ ash.

26. $\quad r a g u=$ guinea worm.

27. $\quad s$ sakk $=$ comb.

28. Šrken $=$ stone beside $\operatorname{tarun}(=\mathrm{P}$. tanur $)$ on which dough is spread in bread baking.

I.I pas $=$ sheep/goat, generic.

I.2 gattor = young male goat.

I.3 gwarag $(o k)=$ baby lamb, unweaned.

I.4 palät $=$ female goat not yet pregnant.

I.5 senik = baby goat.

I.6 trošt $=\mathrm{I} \frac{1}{2}-2$ year old male goat - that most commonly eaten.

2. I $g u k=\mathrm{ox}$ (male or female), generic.

$\left.\begin{array}{l}\text { 2.2.1 } \text { gulu } \\ \text { 2.2.2 } \text { gwašk }\end{array}\right\}=$ calf up to three months old. Cf. Marw: $3^{6}$.

2.3 porräp $=$ young female calf.

$2.4 \quad$ rong $=$ heifer.

2.5 $\quad t \bar{a} b=$ young male calf.

2.6 kärgar $=$ ox used for ploughing.

$\left.\begin{array}{ll}3.1 & \text { gwavz (Sarāvān) } \\ 3.2 & \text { gudar }\end{array}\right\}=$ wasp.

I.I agalinc

I.2 kaṭingbu (Dashtiārī)

I.3 kotomb

I.4 zamini zur

I.5 kïrän-haruk. Cf. Morgenstierne 1957:453

(vii)

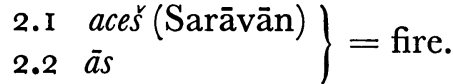
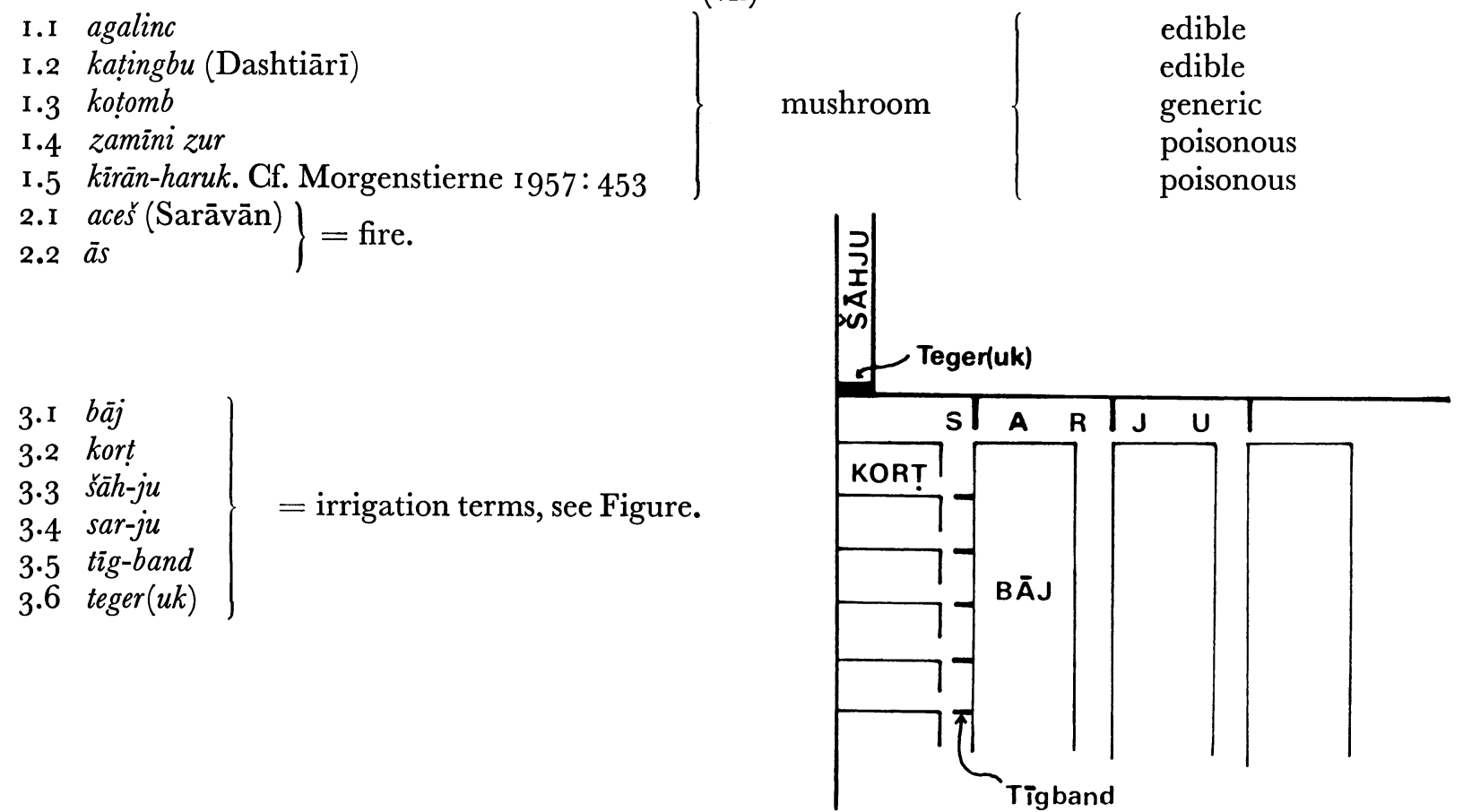

4. Baluc used among the Baluch themselves means pastoralist/nomad as opposed to $\tilde{s}^{2} a h r i=$ settled agriculturalist.

$\left.\begin{array}{ll}5 \cdot \mathrm{I} & (\bar{a} p) \text { band } \\ 5 \cdot 2 & \text { sendät }\end{array}\right\}=$ dam. 
6. $b a s ̌ s=$ summer rain when it continues long enough (i.e. on and off for several weeks) to spoil or endanger the date crop.

$\left.\begin{array}{ll}7.1 & c a \bar{k} \\ 7.2 & \text { gwäp (Sarāvān). Cf. Notes: } 37 \text { and } 45\end{array}\right\}=$ small piles made at reaping.

8. $\operatorname{cammag}($ cam $=$ eye $)=$ spring

9. $\quad$ dagār = cultivated land. Cf. Marw: 34 .

Iо. $d a k k=$ pass

I I. dann = plain (cf. danna = outside)

I2. $\dot{d} a r y \bar{a}=$ river, sea, as in Afghan Persian for the Helmand.

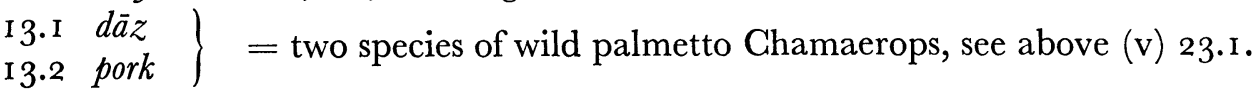

$\left.\begin{array}{l}\text { I4. I duk (cf. Marw: 34, donk?) } \\ \text { I4.2 seng }\end{array}\right\}=$ stone

$\left.\begin{array}{ll}\text { I } 5 . \text { I } & \text { gadd o grändān } \\ \text { I5.2 } & \text { seid }\end{array}\right\}=$ game

I5.3 gadd o wadd = fast high stepping walk (of horse).

16. $g \bar{a}$ ndu $=$ crocodile.

I7. garr $=$ rock or mountain which serves as landmark.

I8. gatt = impassable, of a mountain path. Also in e.g. eda mêrwa/nêrwag gațt int it is impossible to get

fruit here. Cf. Elfenbein, I96 I : 93 n. 6.

I9. $\quad$ gram $=$ piles of gwäp/cāk (cf. above 7) made at reaping. Cf. Misc.: 288.

20. $g u j=$ lizard.

2 I.I guric $=$ north, north wind.

$2 \mathrm{I} .2$ nambi $=$ south.

$2 \mathrm{I} .3 r u-d a r-\bar{a} t=$ east.

$2 \mathrm{I} .4 \quad r u-i-{ }^{-s o d}=$ west.

21.5 magreb $=$ west.

2 I.6 jahl-gwät = south wind.

$2 \mathrm{I} .7 \bar{e}$ r-gwät $=$ east wind.

2 I.8 sar-gwät $=$ west wind.

22. $\quad$ gwahr $=$ cold (noun). mấra gwahr buta $=$ we were cold.

23. $g w a \bar{l}(\operatorname{ag})=$ donkey pannier (P. juwäl). Cf. Notes: 4I, Misc. 288, and Marw: 39, and above (v) 23.5 .

24. $\quad$ gwalm $=$ water left standing in river bed. Cf. Misc.: 288.

25. $g w a n=$ wild pistachio tree (P. ban). Cf. Notes: 50 .

26. $\quad$ gwäng $=$ date palm sapling. Cf. Misc.: 288.

27. $g w a p=$ mat of reeds for stranding fish in a flood.

28. $h \bar{a} r=$ flood - of river in spate.

29. $\quad h a u r=(a)$ rain cloud; $(b)$ rain. Cf. Notes: 46 , and Marw: ig.

3o. $h o s ̌ a p=$ dry farm land, equivalent of P. deim. Also includes land irrigated from flood water.

31. $k a h n=$ P. qanät.

32. $\quad k a n d e g=$ steep path up to mountain pass.

33. $\quad k a r a b=$ sorghum (as a plant), especially when used as fodder.

34. $\quad k a u r=$ river, river bed.

35. I kolont $=$ dates from the time they turn colour (about one month before ripening) until they ripen.

35.2 papok $=$ dates before they become kolont.

$\left.\begin{array}{ll}35 \cdot 3 & \text { hormā (Sarāvān) } \\ 35.4 & n \bar{a}\end{array}\right\}=$ ripe dates.

36. $k$ kntak $=$ thorn.

37. $k r u c=$ non-pedigree date palm and its fruit. Cf. Misc.: 289 .

38. $\quad k u c e k=$ dog. Cf. Marw: 45 .

39. $k u s=$ the heart or cabbage (P. panir) of date palm or palmetto. 
40. lat $/$ lot $=$ stick. Cf. Marw: 54 .

41. lewār = the hot NNW wind which blows during the summer in the Jāz Müriān depression.

Cf. Marw: 54 .

42. $l o r=$ muddy (of water).

43. $\quad l u r=$ dust devil.

$\left.\begin{array}{ll}\text { 44. I } & \text { mac } \\ \text { 44.2 } & \text { mok (Sarāvān). Cf. Redard, I } 962: 2 \text { I } 5 \text { n.2. }\end{array}\right\}=$ date palm.

45. $\quad$ mahär $=$ reins of camel.

46. $\quad n u d=$ low grey cloud, overcast sky, Scotch mist.

47. $\quad$ oläk $=$ general term for any riding animal.

48. I $p a l=$ furrow, also used to refer to sowing in furrows, as opposed to

48.2 sar cand $=$ broadcast sowing.

49. pogol/pogal = frog.

50. pohn/pun = blight; windfall dates; dates turned sour on tree because of damp during baš (above 6).

Cf. Misc.: 290, generally equated with P. pusida.

51. $\quad \check{s} a h r=$ patch of cultivation and/or palm grove, not including dwellings. Cf. Gershevitch, I959: 217.

52. $\quad s \bar{a} n z=$ drizzle, rain not heavy enough to cause rivers to flood (and therefore no use for agriculture throughout most of the Makrān).

53. $\quad$ sink $=$ small white (non-rain) clouds.

54. $s \bar{e} \bar{p} p=$ minor river/ravine in mountains.

55. $\operatorname{sun} z=$ green, algae, e.g. a gwalma šunz gepta = that pool (of stagnant water) has turned green with algae.

56. I sur $=$ mountainside from which the rock splinters and breaks away.

56.2 talär $=$ smooth, firm rock. Cf. Marw: 76 .

57. siah gwät $=$ dust storm.

58. $t^{a} k / t a k s=$ pond for storing water at end of meagre qanät or spring.

59. $\quad$ trampān $=$ rain drops.

6o. trongal $=$ hail.

6r. uteg $=$ (artificially dug) hole for storing rain and flood water (Dashtiārī) for drinking and domestic purposes, P. berka.

(viii)

I.I †brāhondag = close friend, comrade. Cf. parallel P. barädar-khwānda, etc.

I.2 †daz brädar and daz gohär = synonyms (male and female) of brähondag.

2. I $c o k=$ child.

2.2 $\operatorname{mardèn} c o k=$ son, boy.

2.3 janèn cok = daughter, girl, spinster.

3.I destär = fiancée. Cf. Notes, 37, 44 and 52, and Marw: 33 and 34. In the Persian Province it is applied to the girl only. Also used now to mean " girl friend" by Baluch in Tehran.

3.2 wastär (Sarāvān) $\mid=$ fiancé. Cf. parallel P. khwästār = suitor (zāmād also has the same senses as

3.3 zāmäd P. dämäd).

$\left.\begin{array}{ll}3 \cdot 4 & \text { bānur }=\text { bride } \\ 3 \cdot 5 & \text { sălük }=\text { groom }\end{array}\right\}$ i.e. just before and just after the wedding night only.

4. I $\quad b i b i=$ respectful title for (usually elderly) lady.

4.2 banok $=$ as bibi.

5. $\quad$ doksic $=$ sister-in-law (i.e. WZ and HZ, not BW). Cf. Notes: 43-44, and Marw: 33.

6. $h a p u k=$ co-wife. Cf. Notes: 47 .

7.I $j a n=$ wife.

7.2 janèn $=$ one of the species "woman", a woman.

8. I januzān = widow, divorcee. Also found in Brāhui (Marw: 44). 
8.2 saruzān $=$ widower, divorced man.

9. $j \bar{a} r=$ twin.

Io. jowān = young, in prime of life (as warnā below); good, as becomes a warnā.

I . kalmānt $=$ a girl who has " gone sour " (tropš buta), i.e. past marrying age.

12.I $\operatorname{mardom}=$ a person (i.e. without understanding whether man or woman).

I2.2 $\operatorname{mard}=$ husband.

I2.3 $\operatorname{mardèn}=$ one of the species " man" (i.e. sex differentiated), a man.

13. mirwandi $=$ extra share of inheritance given to eldest son before generally equal division of remainder between all sons and daughters.

14. nešăr = sister-in-law, daughter-in-law (i.e. BW, SW; contrast with doksīc above (5), and cf. P. A. 'arüs). Cf. Notes: 44, and Marw: 6r.

I5. I siyäd = relative, any person thought to be related by blood or marriage even though degree may not be known.

I5.2 wäres (A. wärith) = synonym of siyäd.

16. I $\quad$ tru $=$ aunt (FZ and MZ). Cf. Notes: 5 I, and Marw: 77.

I6.2 $n a \bar{k} u=$ uncle (FB and $\mathrm{MB})$.

I 7. $\quad$ warg $=$ (Sarāvān) sister. Elsewhere gohār is used.

18. $w a r n \bar{a}=$ youth, man in the prime of life. Cf. Marw: 8o.

I. äirät = killing animal and cooking and distributing the meat, as at eid Qorbān.

$\left.\begin{array}{l}\text { 2. I } \bar{a} r \bar{s} \bar{\imath} \text { (mainly Sarāvān) } \\ \text { 2.2 sūr, sìr }\end{array}\right\}=$ wedding.

3. $\quad b a \bar{h} u t=$ asylum. Cf. Ulus, July, I964, p. 20.

4. bejjäri = mutual help, especially contributions of relatives towards cost of wedding, to be repaid when the contributor stands in similar need. Cf. Ulus, ibid.

5. $\quad h a \bar{l}=$ exchange of news on meeting. Also simply news, information.

6. $n a d r$ (A. nadhr) in phrase $n a ́ d r-o n=$ A./P. qorbān as a term of address.

7. peil in phrase peil kan = forgive, let bygones be bygones, especially as greeting on eid Qorbān.

8. $\quad$ sāng $=$ marriage, A./P. ezdevāj .

9. saun $=$ divorce.

I. $d a p=$ a mouth. Fig. dápa as a postposition of place-at the mouth of, and in place names, e.g.

Dap-kaur (Sarbāz) = lit. mouth-river (should we expect Kaurdap?).

2. $d \bar{e} m=$ face. Fig. dềma as postposition of place-in front of, and in place names-e.g. Tâp-dem =

lit. facing the sun. Cf. also $\bar{a} \bar{e} m$, etc. Cf. (i) 2.I and I3.I.

3. $g o t=$ throat. Cf. Marw: 39 .

4. gwar in máni gwára = beside me. Cf. also gwar kanag, (ii) 2 I.I 2, ếgo, (i) 2.I and I 3.I.

5. häruk = gum.

6. $k u c=$ eyelid.

7. $k o l o p=$ cheek.

8. $l \bar{a} p=$ stomach. Also as postposition: láp $\bar{a}=$ in the middle of.

9. $m o c \bar{a} c / m e c \bar{a} c=$ eyelash.

I0. $p \bar{a} d=(a)$ foot; $(b)$ spoor, also used for track of motor vehicle. Cf. also páda (with short first $a$ ) as

postposition $=$ on the tracks of, after, and adv. again, back. Cf. also sarpad beag = to understand.

I I. péšañēg/pètok = forehead.

12. sar, as postposition and adverb: sara $=$ on, above; saräter $=$ higher up.

I3.I sont $=$ beak. Cf. Marw: $7 \mathrm{I}$.

I 3.2 sontēg $=$ a particular form of mosquito with a fierce sting in Dashtiāri.

14. $\operatorname{sren}=$ the small of the back, the waist. Cf. Notes: 50, and Marw: $7 \mathrm{I}$. 
(xi)

I.I nän/nagan = bread. The general word used for "a meal". Owing to the fact that breakfast is seldom eaten as an independent meal and the midday meal may be eaten at any time between Io a.m. and 4 p.m., there is some confusion in the usage of the words for these two meals. However,

I.2 nahäri generally and

I.3 nāšta (in Sarāvān) \}are used to mean "breakfast".

I.4 cāšt (Sarāvān) and $\}=$ the midday meal, which is the main meal of the day. (Cf. Marw: 29,

I.5 sobäreg (Makrān) where cāšt is given as meaning " noon, till noon ").

I.6. šäm is used to mean the evening meal.

2.I $b a t t a \bar{g} g=$ eggplant.

2.2 gombak $=$ onion seeds.

2.3. gorja = tomato. Cf. P. gauja (-i farangi $)$.

$2.4 k u s i c=$ marrow.

2.5 kuteg $=$ water melon, P. hendavāna. Cf. Marw: 5o, kutigayt.

2.6 limbu $=$ lime.

2.7 panir $=$ a berry mixed with fresh warm milk to cause it to set, in which condition it also is called panir.

2.8 pima $z=$ onion.

$2.9 s o b=$ local species of apple; P. sib is used for other (imported) varieties of apple.

2. Io tējag = melon, P. xarboza.

2.I I dār-tējag = paw paw, P. xarboza-i deraxtī.

2.12 titok = pomegranate.

3. $b a t=$ cooked rice, P. celau. Cf. Marw: 25, which gives meaning "gruel", and compares Si. bhatt.

4. I $\quad b o c=d u g(\mathrm{P} . d u \gamma)$ when boiled and thickened, but before being dried-when it becomes šilañj (P. kašk, qorut).

4.2 $s a r-d u s ̌$ $=$ fresh (goat's) milk milked directly on to the previous day's $d u g$ - a very refreshing, frothy drink.

4.3 sott $=$ water with a little $d u g$ added. This is thought to be more refreshing, and it improves the taste of bad water. Cf. the A. shanin in Thesiger, Arabian Sands, I 959: I 22. However, the Baluch often drink sott with sweet water.

5. $\quad c a h=$ tea, P. $c \bar{a} i, \ddot{c} \bar{a}-\bar{\imath}$. Cf. Marw: $26, c \bar{a}$, compensating for dropped " $\mathrm{h}$ ".

6. cangāl $=$ preparation of dates and ghee, worked almost to paste consistency.

7.I $\quad$ sohru $=$ red sorghum. C.f. P. sorx = red.

$7.2 m a \bar{k}$

$\left.7 \cdot 3 \begin{array}{cc}m \bar{a} s^{v}\end{array}\right\}=$ types of bean.

8. I $\quad w a \bar{d}=$ salt.

$8.2 w \bar{a} d-\bar{a} p=$ soup. Cf. P. āb-gušt.

I. $\quad b \bar{a} d \bar{a}=$ tomorrow. Cf. Marw: 23 .

2.I $b \bar{e}-g a \bar{h} h=$ late afternoon, towards sunset.

$2.2 b \bar{e}$-wahd (i.e. P./A. bi-vaqt) = late.

3.I dèr, dèr-wahd = a long time ago.

$3.2 z \bar{u} t=$ a short time ago, not long ago.

4. $\quad h \bar{a} m \bar{e} n=$ the period of the date harvest, which is generally July and August. Cf. Notes: 39 and 52 .

5. imbirī imbirigèn säl $=$ this year. Cf. Marw: i 7 .

6. $\quad$ mahalla $=$ (very) early. 
7. $s a b a \hat{a} h \bar{\imath}=$ in the morning, tomorrow morning, as in Afghan Persian. Adverbs of time generally end in $-\bar{\imath}$ : e.g. $\bar{i}-\bar{s} a p \bar{\imath}=$ tonight; marúci, márci, máru = today; puši $=$ the day after tomorrow; duš̀ $=$ last night; parìin, peîri $=$ the day before yesterday; pāri $=$ last year; pérári $=$ the year before last. Cf. also $z \bar{\imath}=$ yesterday and nahär $\bar{\imath}=$ lunch.

8. $\quad$ sarwašan $=$ a period of (relatively) cool weather with better pasture after rain-normally in the spring, but may be at any time of the year.

\section{BIBLIOGRAPHY}

(Works referred to in the text are marked with asterisk)

*. Afshar, I., I 333 A.H.S. "Dìdārī az Sïstān-i Veirāna”, in Yaymā, Vol. VII, no. Iо.

*2. Baluci Zahg Balad, Baluchi Academy, Karachi, 1963. Intended to serve as a first-year school text-book for Pakistāni Baluch children in Pakistan. Standardized Makrānī dialect.

3. Bray, Sir Denys de Saumarez, 1909, Brahui Language, Calcutta. The standard work on Brāhui.

4. Bruce, R. I., 1874, Manual and Vocabulary of the Biluchi Dialect, Lahore. Eastern dialect.

5. Dames, M. L., I88I, A Sketch of the Northern Balochi language, containing a grammar, vocabulary and specimens of the language, Calcutta. Eastern dialect.

6. Dames, M. L. (Compiled) igo4, Text-book ... of the Baluchi language, translated into English by R. S. Diwan Jamiat Rai, with the assistance of Munshi Dur Muhammad, Lahore. Eastern dialect.

*7. Dames, M. L., 1907, Popular Poetry of the Baloches, Royal Asiatic Society. 2 vols. Standard published work on Baluch poetry but transcribed from Eastern dialect.

8. Dames, M. L., I913, "Balochistan" in Encyclopédie de l'Islam. Includes account of Baluch history and language (eastern dialect), and bibliography complete up to I913.

9. Dames, M. L., 1922, A Text-book of the Balochi language, consisting of miscellaneous stories, legends, poems, and Balochi-English vocabulary, Lahore. Eastern dialect.

ı. Elfenbein, J., I96o, "Baluchistan. B. Language", in Encyclopaedia of Islam. General, philological account.

* I I. Elfenbein, J., I96I, "A Baluci Text, with translation and notes" in BSOAS, XXIV, I, pp. 86-103. Popular story in Makrāni dialect.

*12. Elfenbein, J., 1963, A Vocabulary of Marw Baluchi, Naples. Etymological glossary of published texts of the Marw dialect.

* I3. Emeneau, M. B., I964, "Linguistic Desiderata in Baluchistan" in Indo-Iranica, Mélanges présentés à Georg Morgenstierne, Harrassowitz, pp. 73-7. On the relationship between Baluchī and Brāhui.

*I4. Frolova, V. A., 196o, Beludžskij yazyk, Moscow. Latest and most lengthy (approximately 7o pp.) descriptive grammar; bibliography complete to 1960 .

* I5. Frye, R., I33 I A.H.S. (a) "Safar-i Biyābānak va Sistān va Balucistān ", Dānesh, Vol. II, nos. Io/I I, Tehran.

* I6. Frye, R., I 33 I A.H.S. (b) “Taṭbiq-i lahja-hā-i Khẉuri va Baluci ", Mehr, vol. VIII, nos. 3 and 4 , Tehran.

17. Geiger, W., r 89o, Etymologie des Baluci, München.

18. Geiger, W., I891, Lautlehre des Baluci, mit einem Anhange über Lehnwörter im Baluci, München.

*19. Geiger, W., I895-1903, "Die Sprache der Balutschen" in Grundriss der Iranischen Philologie, Band I, Abteilung 2. These three works of Geiger's may still be considered standard general works on the Baluchi language.
*20. Gershevitch, I., I959, " Travels in Bashkardia " in $R C A S$, XLVI, 3 and 4, pp. 2 I3-25. Includes some philological and ethnographical material from Bashkardia relevant to Baluchī and Baluchistān.

2 1. Gershevitch, I., 1962, "Outdoor Terms in Iranian" in $A$ Locust's Leg, Studies in honour of S. H. Taqizadeh, pp. 76-84.

22. Gershevitch, I., 1964, "Iranian Chronological Adverbs" in Indo-Iranica, pp. 78-88.

These two works include discussion of some Baluchi and Bashkardi terms.

23. Gilbertson, G. W., I923, The Balochi Language: a grammar and manual, assisted by Ghano Khan, Haddiani.

24. Gilbertson, G. W., I925, English-Balochi colloquial dictionary, assisted by Ghano Khan.

Both these works are confined to the Eastern dialect.

25. Gladstone, C. E., I874, Biluchi Handbook. Assisted by Hetu Ram and Mean Jiwan, munshis, Lahore. Eastern dialect.

*26. Grierson, G. A., 1921, "Balōchi" in The Linguistic Survey of India, Calcutta, vol. X. Standard work, includes general grammar, word list, irregular verb stems, texts, and indicates main differences between eastern and western dialects.

27. Hetu Ram, Rai Bahadur (Compiler), I885, Translation of Bilochi-Nama, Calcutta. Includes grammar, verb-list, conversation, stories, vocabulary-in eastern dialect only.

28. Hughes, A. W., I877, The country of Balochistan, its geography, topography, ethnology and history; with a map, photographic illustrations, and appendices containing a short vocabulary of the principal dialects in use among the Balochis ... London.

29. Leech, R., I838, Epitome of the grammar of the Brahuiky, the Balochky and the Panjabi languages . . . Calcutta, Asiatic society of Bengal. Eastern dialect.

3o. Lewis, A., 1885 , Bilochi stories as spoken by the nomad tribes of the Sulaiman hills, Allahabad. Eastern dialect.

31. Marston, E. W., I888, Lessons in the Makrani-Baluchi Dialect, Karachi.

32. Marston, E. W., i 877 , Grammar and vocabulary of the Mekranee Beloochee dialect, Bombay.

*33. Marw-see Elfenbein, 1963.

34. Mayer, T. J. L., I900-ıgo I, Balōch Classics, Fort Munro and Agra. Eastern dialect.

35. Mayer, T. J. L., г910, English-Biluchi dictionary, Calcutta. Eastern dialect.

*36. Misc., see Morgenstierne, I 948 .

37. Mockler, E., I877, A grammar of the Baloochee language as it is spoken in Makran ...., London.

*38. Morgenstierne, G., I932a, Report on a linguistic mission to $\mathcal{N}$.W. India, Oslo. Starts with observations on Baluchī and Brāhui contacts. 
*39. Morgenstierne, G., I 932b, "Notes on Balochi Etymology" in Norsk tidsskrift for sprogvidenskap, V, pp. 37-53. Discussion of words from his material " which appear to be of genuine Bal. origin, and which are not found in Geiger...".

*40. Morgenstierne, G., 1947, "Balochi Language" in the Encylopaedia Britannica II (also in I 957 ed.). Best short general account of the language.

*41. Morgenstierne, G., 1948, "Balochi Miscellanea" in Acta Orientalia, XX, pp. 253-92.

*42. Morgenstierne, G., r 957 , " 'Mushroom' and 'Toadstool' in Indo-Iranian" in $B S O A S, \mathrm{XX}, \mathrm{pp} .45 \mathrm{I}-57$.

43. Morgenstierne, G., I958, "Neu-Iranische Sprachen" in Handbuch der Orientalistik Abteilung $\mathrm{I}$, Band 4 , Abschnitt I pp. I55-78.

* 44. Notes-see Morgenstierne, i932b.

45. Pierce, E., I 875, "A Description of the Mekranee-Belochee Dialect" in $\mathcal{F} R A S$ (Bombay), XI.
*46. Redard, G., I962, "Le Palmier à Khur. Notes de dialectologie iranienne I", in A Locust's Leg. Comparative Iranian vocabulary relative to date palm culture.

47. Sokolov, S. N., 1956, "Grammatičeskij očerk jazyka Beludžej Sovetskogo Sojuza", in Trudy Instituta Fazykoznanija, VI, pp. 57-91. Marw dialect.

48. Sokolova, V. S., 1953, "Beludžskij jazyk" in Očerki po fonetike iranskix jazykov, I, pp. 7-77. Concerns phonetics of Marw dialect only.

49. Weryho, J. W., I962, "Sīstāni-Persian Folklore" in IndoIranian Fournal, $\mathrm{V}$, No. 4.

50. Zarubin, I., I930, " $\mathrm{K}$ izučeniju beludžskogo jazyka i Fol'klora ", in Zapiski kollegii vostokovedov, V, pp. 653-79.

51. Zarubin, I., 1932, Beludžskije skazki I (1932), II (1949). Both restricted to the Marw dialect. 